\title{
The Basic Strategy of Academic Management in Undergraduate Universities
}

\author{
Aying Zhang ${ }^{1, a,{ }^{*}}$, Zhiping $\mathrm{Li}^{1, \mathrm{~b}}$, Zhenghong Li ${ }^{2, \mathrm{c}}$ \\ ${ }^{1}$ Harbin University, 150086 Harbin, China \\ ${ }^{2}$ Harbin Institute of Technology, 150001 Harbin, China \\ a,*zaying@sina.com, blizp2008@126.com, c273662999@qq.com
}

Keywords: Basic strategy, Academic management, Undergraduate, Universities.

\begin{abstract}
The academic management of undergraduate universities is the management of academic activities and academic affairs of undergraduate universities according to the inherent logic of knowledge and the laws of teaching and scientific research. Thus it can be seen that the object of academic management of undergraduate universities is the academic affairs and activities of undergraduate universities. Non-academic management refers to the management of various non-academic affairs, such as general affairs, logistics and so on, which support, standardize and restrict undergraduate universities. According to the relationship between academic administration and academic democratic management, we divide the academic management of undergraduate universities into three stages: the first stage is called the teaching stage, the second stage is called the academic management stage, and the third stage is called the academic management stage.
\end{abstract}

\section{Academic management and administration of undergraduate university}

\subsection{Connotation of academic management and administration}

\subsubsection{Adjusting professional structure and adapting to social needs}

The research shows that learning is the unity of cognition and behavior. Modern Chinese Dictionary holds that learning is the systematic specialized knowledge, that is, the system of specialized knowledge reflecting objective things. Ernest Boyer, an American higher education theorist, holds that learning is the discovery of learning (discovering new knowledge through research). Knowledge, integrated learning (synthesizing knowledge through curriculum development), applied learning (discovering certain ways to link knowledge to contemporary problems) and teaching learning (imparting knowledge through consultation or teaching). We believe that there are narrow sense, middle meaning and broad sense in academic studies.

Academy in a narrow sense refers to the process and achievements of scientific research, that is, the behavior of scientific research and the system of expertise acquired; Academy in a middle sense refers to the process and achievements of research, that is, the narrow sense of learning and teachers' research teaching; Academy in a broad sense refers to the undergraduate university's teaching, scientific research, enrollment, academic, communication and other processes and achievements. This book refers to the broad sense of scholarship.

\subsubsection{Connotation of academic management in Undergraduate Universities}

Academic management includes teaching management, scientific research management, teacher management, enrollment management and so on. The essence of academic management lies in coordination, standardization and control. Academic management is the core of University management.

\subsubsection{Connotation of administrative management in Undergraduate Universities}

According to administration, administration refers to the state's management of public affairs, mainly the government's management of various social undertakings, and its modern institutional form is hierarchy. The administrative management of undergraduate universities refers to the process and 
result of the undergraduate universities' management of their internal affairs under the bureaucratic system.

\section{Academic democratic management of Undergraduate Universities}

\subsection{Academic democratic management}

As academic affairs are the main affairs of undergraduate universities, academic management is the main content of the management of undergraduate universities. In academic management, management can be a hierarchical management, that is, the administrative management of academic affairs, referred to as academic administration, academic administration has a high center of gravity, centralization and mandatory characteristics.

Management can also be democratic management, that is, democratic management of academic affairs, referred to as academic democratic management, academic democratic management with a low center of gravity, decentralization, non-mandatory and other characteristics.

The institutional framework of academic administration is a hierarchical system, the management principle is that the principal is responsible for the system and the subordinates obey the superiors, the management activities abide by various management rules and regulations; the main body of academic democratic management is the academic committee (professor's association), the management principle is peer expert review, and the management method is to discuss and reach a consensus.

\subsection{Characteristics and principles of academic democratic management in Undergraduate Universities}

\subsubsection{Characteristics of academic democratic management in undergraduate universities}

Democratic management of academic democracy in undergraduate universities: academic activities in universities are carried out and completed by the majority of teachers. Academic democratic management must be approved and supported by the majority of teachers. Democracy is the main way to get the approval and support of the majority of teachers.

The scientific management of academic democracy in undergraduate universities: the scientific nature of academic democratic management in universities is determined by the exploratory activities of academic activities. Academic democratic management should be managed according to the internal regularity of academic activities, which is the main connotation of scientific academic management.

The diversity of academic democracy management in undergraduate universities: because different disciplines have their own characteristics, academic democratic management will inevitably show diversity.

\subsubsection{Principles of academic democratic management in undergraduate universities}

The principle of academic freedom: when there are different opinions in academic circles, consensus can be gradually achieved through full and free discussion.

Democratic management principles: the decision and management of academic affairs must rely on professors and experts and democratic management.

Bottom-up principle: the focus of academic management should be placed on discipline and practice, and bottom-up management should be carried out.

\section{Main approaches to academic management in Undergraduate Universities}

\subsection{The teaching and learning stage of academic democratic management}

The main characteristics of the teaching stage of professors of academic democratic management are as follows: academic administration is dominant, academic democratic management is auxiliary, that is, administrative system with bureaucracy as its carrier manages academic affairs and activities of undergraduate universities subjectively. 
The institutional framework of the teaching stage of professors in academic democratic management is that the management system is hierarchical, the leadership system is the headmaster responsibility system under the leadership of the Party committee, the academic advisory body is an academic committee or a professor's association, the management principle is democratic centralism and the subordinate obeys the superior, and the behavior norms are rules and regulations. In the teaching stage of professors of academic democratic management, administrative power plays a major role in academic affairs and activities, that is, academic administration plays a major role; while academic power is in a marginal position, that is, the marginalization of academic democratic management. In the teaching stage of academic democratic management, teachers (professors) mainly teach, and the influence of teachers (professors) on academic affairs and activities is advisory; in academic institutions (academic committees or professors' associations) and democratic organizations (trade unions or congresses), administration plays a leading role. In the teaching stage of professors of academic democratic management, administrative power extensively controls academic affairs and activities, and academic affairs and activities are severely restrained.

\subsection{Academic management of Academic Democracy}

The main characteristics of professors in academic democratic management are: decision-making of academic democratic management, execution of academic administration, that is, scientific decision-making of academic affairs by academic organizations with academic committees or professors' associations as carriers, and administrative system with bureaucratic system as carriers. The institutional framework of the professor's stage of academic democratic management is as follows: the administrative system is still hierarchical, and the leadership system is still the headmaster's responsibility system under the leadership of the Party committee. However, academic committees or professors' associations and other academic institutions make decisions on academic affairs and activities subjectively, that is, the science in which the academic democratic management system is responsible for academic affairs and activities. Decision-making; and the administrative system is responsible for efficient implementation in accordance with subordinate obedience to higher levels and rules and regulations.

At the stage of professor administration in academic democratic management, administrative system and academic system play a parallel role in academic affairs and activities, that is, administrative power and academic power together determine the direction of academic affairs, academic committees or professors' associations as the carrier of academic affairs for scientific decision-making, administrative organs. The executive body for the carrier is efficient in executing the decisions of academic institutions. At the stage of Professor administration in academic democratic management, teachers (professors) not only teach, but also make decisions on academic affairs and activities through academic institutions (academic committees or faculty associations) and democratic organizations (trade unions or congresses). At this time, academic freedom is reflected to a certain extent.

For undergraduate universities, it is an important task at this stage to do a good job in the system design of academic administration decision-making and the implementation of academic democratic management. First, we should straighten out the relationship between academic democratic management institutions and academic administrative agencies, clearly divide the scope of responsibility and authority of the two types of institutions, so that they have both division of labor and cooperation, and at the same time, we should keep the relationship between academic democratic management institutions at all levels and various types of academic democratic management institutions in harmony. Secondly, we should establish and improve the operational mechanism and rules of democratic management, such as deliberation and consultation, decision-making, command and execution, supervision and guarantee of academic affairs, ensure the principal position and role of teachers, establish standardized academic democratic procedures and communication channels, and perfect an objective and just academic evaluation mechanism. At the same time, the academic democratic management system of colleges and departments should be established and perfected. According to the governance theory of multi-subject, common goal, rational decentralization, 
partnership, coordination and cooperation, the allocation of responsibilities and rights of academic democratic management among colleges, colleges and departments should be systematically designed, and the universities should be established to meet the requirements of academic development of undergraduate universities. The academic and democratic management structure was matched by three levels of responsibility and power.

In other words, the establishment of the structure of dividing and ruling the departments of undergraduate universities gives the departments' relatively complete and independent administrative authority over the internal disciplines and specialties. The system of dividing and governing colleges and departments requires universities to change the way of administrative management of colleges and departments, to change the administrative instructions into consultation and coordination, and to establish a governance system in which teachers, students and other stakeholders participate extensively, that is, a harmonious management system.

\subsection{Academic management of Academic Democracy}

The main characteristics of professors in the stage of academic democratic management are as follows: academic democratic management is dominant and academic administrative management is auxiliary. The institutional framework of professors in the stage of academic democratic management is as follows: the management system is still hierarchical, but the leadership system should be the responsibility of the board of directors and other academic institutions such as academic committees or professors' associations manage academic affairs and activities subjectively, that is, the academic democratic management system is responsible for the management of academic affairs and activities.

Under the condition of flat management level, the administrative system can be implemented efficiently in accordance with the requirements of academic departments and rules and regulations. In the stage of professor administration under academic democratic management, academic power determines the direction of academic affairs. Academic organizations, such as academic committees or professors' associations, carry out comprehensive management of academic affairs, and administrative agencies serve academics and cooperate with academic institutions efficiently.

In the stage of professor administration in academic democratic management, teachers (professors) not only carry out teaching work, but also manage academic affairs and activities through academic institutions (academic committees or professors' associations) and democratic organizations (trade unions or congresses), and influence administrative management through the selection of principals and other administrative personnel. . At this point, academic freedom has been fully reflected.

\section{Acknowledgement}

This research was financially supported by Heilongjiang Social Science Foundation (Grant No. 17SHD204).

\section{References}

[1] Z. P. Li, W. D. Wu: China Higher Education Research vol. 6 (2005), pp. 39

[2] Z. P. Li: Heilongjiang Researches on Higher Education vol. 3 (2005), pp. 22

[3] Z. P. Li: Education Exploration vol. 4 (2005), pp. 38

[4] Z. P. Li and et al: Journal of Harbin University vol. 10 (2005), pp. 64

[5] Z. P. Li, W. D. Wu: China Higher Education Research vol. 7 (2006), pp. 56 